\title{
PENGELOLAAN DAN PENGOLAHAN SAMPAH PASAR DESA GUDANG TENGAH MELALUI KONSEP 3 R DAN TEKNOLOGI LINGKUNGAN
}

\author{
${ }^{1}$ Adhi Surya \\ ${ }^{2}$ Dewi Ariefahnoor \\ ${ }^{1}$ Dosen Prodi (S-1) Teknik Sipil, Fakultas Teknik, Uniska MAB \\ ${ }^{2}$ Dosen Prodi (S-1) Manajemen, Fakultas Ekonomi, Uniska MAB \\ Jalan Adhyaksa No. 2, Banjarmasin, Kalimantan Selatan 70123 \\ E-mail: adhisurya1998@gmail.com/HP +6282116726469
}

\begin{abstract}
ABSTRAK
Permasalahan lingkungan hidup yang terjadi di berbagai daerah pada saat ini adalah penurunan daya dukung lingkungan sebagai akibat rendahnya kesadaran masyarakat terhadap pentingnya pengelolaan lingkungan hidup. Hal ini dipicu oleh beberapa faktor, antara lain perubahan fungsi dan tatanan lingkungan, penurunan daya dukung lingkungan dan mutu lingkungan, tidak adanya keterpaduan pengelolaan sumber daya manusia, alam, dan buatan dalam pengelolaan lingkungan hidup antar berbagai pihak, kurang optimalnya pemanfaatan ruang kota, serta pencemaran lingkungan yang dihasilkan oleh adanya sampah. Tujuan suatu sistem pengelolaan sampah ialah mengkonversi sampah menjadi bahan yang berguna secara efisien dan ekonomis dengan dampak lingkungan seminimal mungkin. Untuk melakukan konversi sampah diperlukan adanya informasi tentang karakter sampah, karakter teknis teknologi konversi yang ada, karakter pasar dari produk pengolahan, implikasi lingkungan, persyaratan lingkungan, dan ketersediaan dana. Aktifitas pasar subuh desa gudang tengah dimulai dari jam 00.00 s.d. 08.00 WITA. Untuk aktifitas pasar tidak berhenti kecuali hari libur Agama Islam. Kebanyakan barang yang didagangkan adalah jenis sayur-mayur, buah-buahan dan ikan yang hidup. Terbukti dari sampah yang banyak adalah jenis sayur-mayur dan buah-buahan serta jenis sampah plastik. Pengelolaan Sampah Pasar melalui konsep 3R (Reduce-ReuseRecycle) dan Teknologi lingkungan. Oleh karena itu dipandang perlu untuk melakukan pengelolaan pasar subuh Desa Gudang Tengah Kabupaten Banjar dalam program Pengabdian Kepada Masyarakat (PKM) Universitas Islam Kalimantan Muhammad Arsyad Al Banjari Banjarmasin dengan mitra Desa Gudang Tengah Kabupaten Banjar.
\end{abstract}

Kata Kunci : Pengelolaan Sampah Pasar, Konsep 3 R, Teknologi Lingkungan, PKM dan Desa Gudang Tengah Kabupaten Banjar.

\begin{abstract}
Environmental problems that occur in various regions at this time are a decrease in the carrying capacity of the environment as a result of the low awareness of the community on the importance of environmental management. This was triggered by several factors, including changes in environmental functions and order,
\end{abstract}


decreased environmental carrying capacity and environmental quality, lack of integration of human, natural and man-made resources in environmental management between various parties, less optimal use of urban space, and environmental pollution produced by the presence of garbage. The goal of a waste management system is to convert waste into useful materials efficiently and economically with minimal environmental impact. To convert waste, information is needed about the character of waste, the technical character of existing conversion technology, the market character of processing products, environmental implications, environmental requirements, and availability of funds. Market activity at dawn in the middle of warehouse village starts from 00.00 untill 08.00 WITA. And market activity does not stop except Islamic holidays. Most items traded are living vegetables, fruits and fish. Evidenced by a lot of garbage is the type of vegetables and fruits as well as the type of plastic waste. Market Waste Management through the concept of $3 R$ (Reduce-Reuse-Recycle) and environmental technology. Therefore it is deemed necessary to manage the dawn market of Gudang Tengah Village in Banjar Regency in the Community Service Program (PKM) of the Kalimantan Islamic University Muhammad Arsyad Al Banjari Banjarmasin with partners in Gudang Tengah Village in Banjar Regency.

Keywords: Market Waste Management, 3R Concept, Environmental Technology, PKM and Gudang Tengah Village, Banjar Regency.

\section{PENDAHULUAN}

\section{Latar Belakang}

Permasalahan lingkungan hidup yang terjadi di berbagai daerah pada saat ini adalah penurunan daya dukung lingkungan sebagai akibat rendahnya kesadaran masyarakat terhadap pentingnya pengelolaan lingkungan hidup. Hal ini dipicu oleh beberapa faktor, antara lain perubahan fungsi dan tatanan lingkungan, penurunan daya dukung lingkungan dan mutu lingkungan, tidak adanya keterpaduan pengelolaan sumber daya manusia, alam, dan buatan dalam pengelolaan lingkungan hidup antar berbagai pihak, kurang optimalnya pemanfaatan ruang kota, serta pencemaran lingkungan yang dihasilkan oleh adanya sampah.

Perkembangan ilmu pengetahuan dan teknologi khususnya teknologi informasi pada saat ini sangat mendukung dalam penyediaan informasi lingkungan. Melalui teknologi intranet maupun internet arus informasi mengenai permasalahan lingkungan dan penanganannya dapat dilakukan dengan mudah.

Kebijakan Otonomi Daerah sebagaimana dirumuskan dalam Undang-Undang Nomor 22 Tahun 1999, secara eksplisit menegaskan adanya otoritas pemerintah daerah untuk mengurus dan mengelola berbagai sektor pembangunan dengan inisiatif dan prakarsa kreatif bagi kepentingan dan kesejahteraan rakyat daerah. Kewenangan yang utuh sejak perencanaan, pelaksanaan, dan pengawasan dalam pemerintahan serta pembangunan mengandung konsekuensi tanggung jawab yang tidak kecil, antara lain: peningkatan profesionalitas sumber daya manusia dan institusi di daerah, penyesuaian struktur organisasi guna mengakomodasi urusan 
yang semakin besar, mengenali potensi daerah secara utuh dan lengkap sebagai modal dasar pembangunan daerah dan penataan ulang berbagai kebijakan yang menyangkut sumberdaya nasional di daerah.

Bentuk pemanfaatan sesuai Pasal 10 ayat (1) dari Undang-Undang Nomor 22 Tahun 1999, adalah: Daerah berwenang mengelola Sumberdaya Nasional yang tersedia di wilayahnya dan bertanggung jawab memelihara kelestarian lingkungan sesuai dengan peraturan perundang-undangan. Selanjutnya dalam penjelasan Pasal 10, ayat (1), menyatakan bahwa yang dimaksud dengan sumberdaya nasional adalah sumberdaya alam dan lingkungan hidup, sumberdaya buatan, dan sumberdaya manusia yang tersedia di daerah.

Tujuan suatu sistem pengelolaan sampah ialah mengkonversi sampah menjadi bahan yang berguna secara efisien dan ekonomis dengan dampak lingkungan seminimal mungkin. Untuk melakukan konversi sampah diperlukan adanya informasi tentang karakter sampah, karakter teknis teknologi konversi yang ada, karakter pasar dari produk pengolahan, implikasi lingkungan, persyaratan lingkungan, dan ketersediaan dana.

Salah satu bentuk tanggung jawab dosen dalam melaksanakan tridarma perguruan tinggi untuk kepentingan masyarakat adalah Pengabdian Kepada Masyarakat (PKM). PKM dipandang perlu dilakukan sebagai sarana untuk menjembatani kampus dengan masyarakat. Sebagai realisasi pelaksanaan PKM UNISKA MAB yang saat ini diperlukan oleh pengelola pasar subuh Desa Gudang Tengah adalah pengelolaan dan pengolahan sampah dengan metode sederhana yaitu konsep $3 \mathrm{R}$ dan Teknologi Lingkungan.

Letak Desa Gudang Tengah berada di sebelah Timur Desa Pejambuan dengan luas wilayah 2,85 km2 dan jarak Desa Gudang Tengah ke Ibukota Kecamatan 1,5 km serta jarak ke Ibu Kota Kabupaten sekitar 21,5 km, peta disajikan pada Gambar 1.

Batas-batasnya adalah sebagai berikut :

- Sebelah Utara : Desa Lok Buntar

- SebelahTimur : Desa Pejambuan

- Sebelah Selatan : Desa Pematang Panjang

- Sebelah Barat : Desa Sungai Tabuk Kota

- Keadaan topografi : Secara Umum merupakan daerah pertanian

- Iklim : Mempunyai iklim tropis (dua musim) 


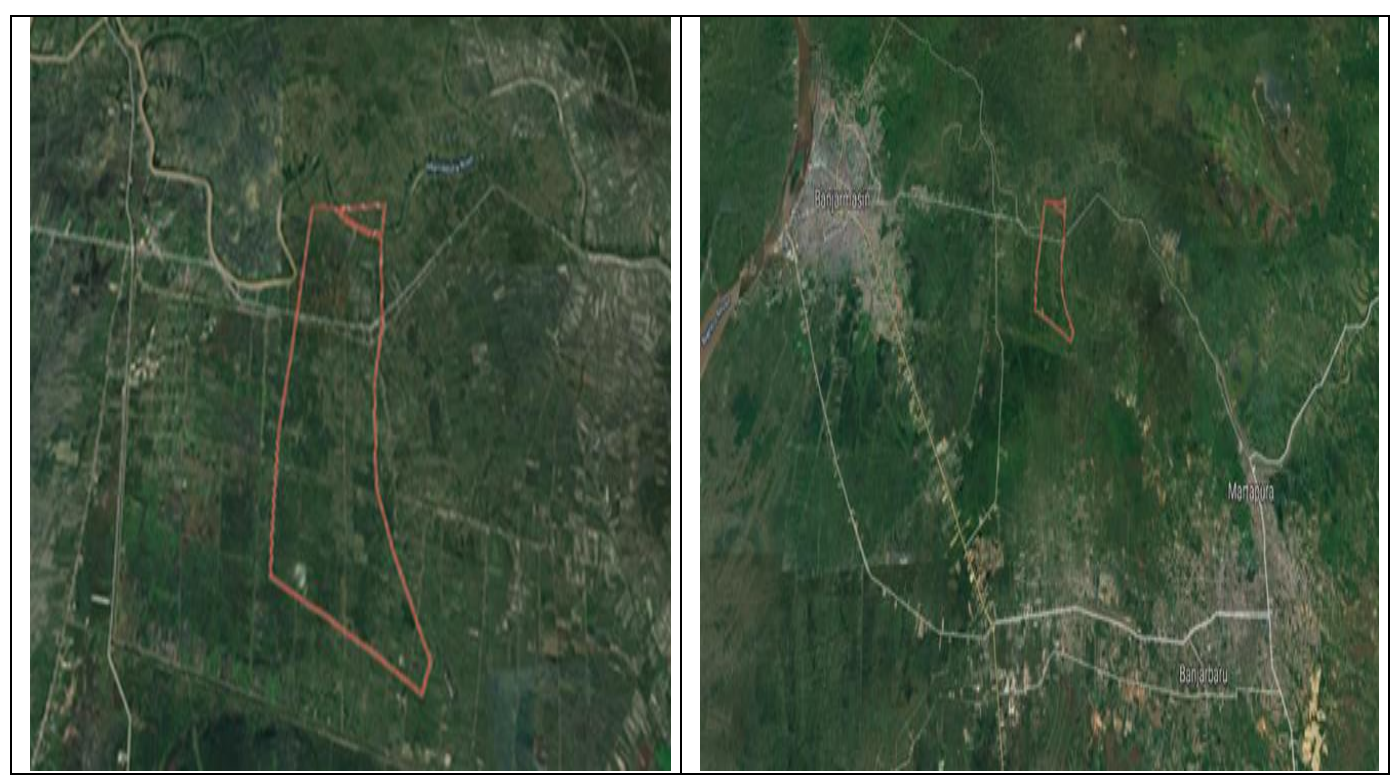

Gambar 1. Desa Gudang Tengah dan Jarak DGT ke BJM

(Sumber : www.google.co.id/maps)

Secara umum mata pencaharian warga masyarakat Desa Gudang Tengah atau jumlah penduduk berdasarkan mata pencaharian dapat dilihat dalam Tabel 1.

Tabel 1. Mata Pencaharian Penduduk Desa Gudang Tengah

\begin{tabular}{|c|l|c|}
\hline No & \multicolumn{1}{|c|}{ Mata Pencaharian } & Jumlah \\
\hline 1 & PNS & 7 \\
\hline 2 & Pensiunan & 2 \\
\hline 3 & Petani & 40 \\
\hline 4 & Wiraswasta & 23 \\
\hline 5 & Pedagang & 202 \\
\hline 6 & Buruh Harian Lepas & 5 \\
\hline 7 & Guru & 2 \\
\hline 8 & Perawat / Bidan & 276 \\
\hline 9 & Pelajar / Mahasiswa & 26 \\
\hline 10 & Sopir & 469 \\
\hline 11 & Mengurus Rumah Tangga & 197 \\
\hline 12 & Belum Bekerja & 545 \\
\hline 13 & Tidak Bekerja & 6 \\
\hline 14 & Tukang Kayu & 1 \\
\hline 15 & Mekanik & 2 \\
\hline 16 & Karyawan Honor & 1 \\
\hline 17 & Ustadz & 4 \\
\hline 18 & Buruh Industri & 31 \\
\hline 19 & Karyawan Swasta & $\mathbf{2 . 1 5 9}$ \\
\hline & & \\
\hline
\end{tabular}

Sumber : Data Potensi Desa Gudang Tengah, 2019 
Terlihat pekerjaan pedagang berjumlah 23 orang, wiraswata 311 orang, karyawan swasta 31 orang, petani berjumlah 40 orang, supir 26 orang, buruh harian lepas 202 orang, dan buruh Industri 4 orang, tukang kayu 6 orang, mekanik 1 orang, karyawan honor desa 2 orang, PNS 7 orang, Pensiunan PNS 2 orang, guru 5 orang, ustadz 1 orang, Perawat/Bidan 2 orang, Pengurus Rumah Tangga (IRT) sebanyak 469 orang. Sedangkan yang belum bekerja 197 orang, tidak bekerja 545 orang dan pengangguran terselubung (pelajar/mahasiswa) sebesar 276 orang. Bisa disimpulkan pengangguran sebanyak $47,15 \%$ sisanya bekerja $52,85 \%$. Dikatakan Desa Gudang Tengah sebagai Desa pekerja sebesar 52,85\%.

Rukun Tetangga (RT) sebagai bagian dari satuan wilayah Pemerintah Desa memiliki fungsi yang sangat dominan dalam pelayanan kepentingan masyarakat wilayah tersebut. Terutama berkaitan hubungannya dengan Pemerintahan pada level di atasnya. Struktur Kepemimpinan Desa Gudang Tengah dengan segala hirarkinya dapat dilihat dalam bagan dibawah ini :

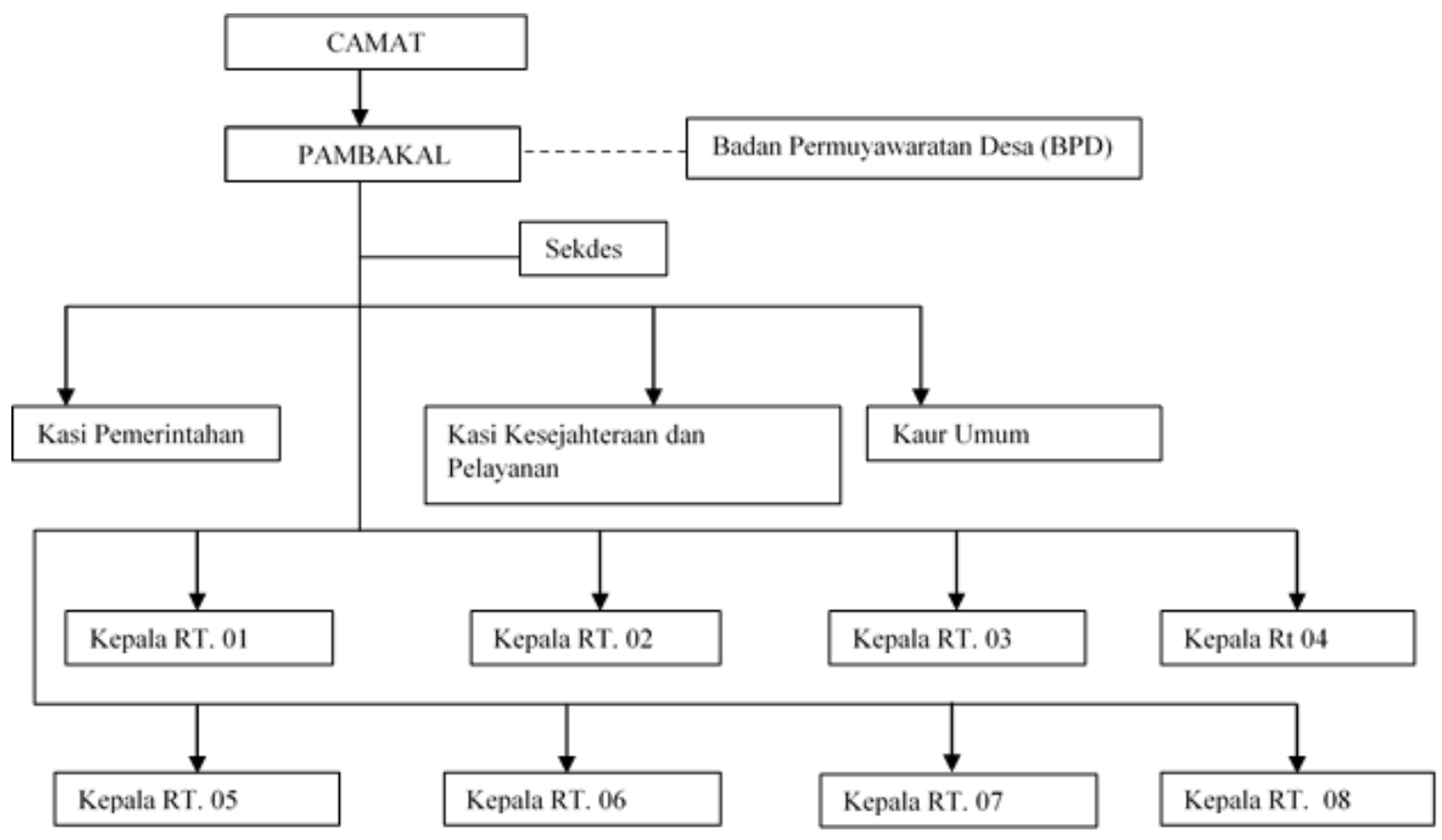

Gambar 2. Struktur Organisasi Pemerintahan Desa Gudang Tengah

(Sumber : Data Potensi Desa Gudang Tengah, 2019)

Berdasarkan Data Administrasi Pemerintahan Desa, jumlah penduduk yang tercatat secara administrasi, jumlah total 2.159 jiwa. Dengan rincian penduduk berjenis kelamin Laki-laki, berjumlah 1.120 jiwa, sedangkan berjenis kelamin perempuan berjumlah 1.039 jiwa. Survei Datadilakukan olehFasilitator Pembangunan Desa, dimaksudkan sebagai data pembanding dari data yang ada di Pemerintah Desa. Dengan melakukan survei di masyarakat maka didapatkan data seperti yang ada pada Tabel 2 dan Tabel 3. 
Tabel 2. Jumlah Penduduk Berdasarkan Jenis Kelamin Desa Gudang Tengah

\begin{tabular}{|c|l|c|}
\hline No & \multicolumn{1}{|c|}{ Jenis Kelamin } & Jumlah \\
\hline 1 & Laki-Laki & 1.120 \\
\hline 2 & Perempuan & 1.039 \\
\hline \multicolumn{2}{r|}{} & Total \\
\hline
\end{tabular}

Sumber : Data Potensi Desa Gudang Tengah, 2019

Berdasarkan Tabel 2. Jumlah laki-laki dan perempuan berimbang saja. Masih didominasi jumlah laki-laki sebesar 1120 orang dan perempuan 1039 orang.

Tabel 3. Jumlah Penduduk Desa Gudang Tengah Berdasarkan Tingkatan Usia

\begin{tabular}{|c|l|c|}
\hline No & \multicolumn{1}{|c|}{ Kelompok Usia } & Jumlah \\
\hline 1 & Balita & 86 \\
\hline 2 & Anak-Anak & 238 \\
\hline 3 & Remaja & 567 \\
\hline 4 & Dewasa & 812 \\
\hline 5 & Lansia & 393 \\
\hline 6 & Manula & 63 \\
\hline \multicolumn{2}{r|}{} \\
\hline
\end{tabular}

Sumber : Data Potensi Desa Gudang Tengah, 2019

Dalam hal Pendidikan satu hal penting dalam memajukan tingkat kesejahteraan pada umumnya dan tingkat perekonomian pada khususnya. Dengan tingkat pendidikan yang tinggi maka akan mendongkrak tingkat kecakapan. Tingkat kecakapan akan mendorong tumbuhnya ketrampilan kewirausahaan. Dan pada gilirannya mendorong munculnya lapangan pekerjaan baru. Dengan sendirirtya akan membantu program pemerintah untuk pembukaan lapangan kerja baru guna mengatasi pengangguran. Pendidikan biasanya akan dapat mempertajam sistimatika pikir atau pola pikir individu, selain itu mudah menerima informasi yang lebih maju. Dibawah ini Tabel 4 yang menunjukan tingkat rata-rata pendidikan warga Desa Gudang Tengah

Tabel 4. Tingkat Pendidikan Masyarakat yang ada di Desa Gudang Tengah

\begin{tabular}{|c|l|c|}
\hline No & \multicolumn{1}{|c|}{ Jenjang Pendidikan } & Jumlah \\
\hline 1 & Tidak Sekolah & 358 \\
\hline 2 & Belum Tamat SD & 248 \\
\hline 3 & Tidak Tamat SD & 145 \\
\hline 4 & Tamat SD & 745 \\
\hline 5 & Tamat SLTP & 316 \\
\hline 6 & Tamat SLTA & 250 \\
\hline 7 & Tamat Akademi / Perguruan Tinggi & 97 \\
\hline \multicolumn{2}{|r|}{ Total } & 2.159 \\
\hline
\end{tabular}

Sumber : Data Potensi Desa Gudang Tengah, 2019

Jumlah penduduk per RT Desa Gudang Tengah bisa dilihat dalam Tabel 5 sebagai berikut : 
Tabel 5. Jumlah Penduduk per RT Desa Gudang Tengah

\begin{tabular}{|c|c|c|c|c|}
\hline RT & Jumlah Penduduk & Laki-laki & Perempuan & Jumlah KK \\
\hline 01 & 172 & 91 & 81 & 69 \\
\hline 02 & 234 & 118 & 116 & 75 \\
\hline 03 & 344 & 183 & 161 & 89 \\
\hline 04 & 261 & 142 & 119 & 65 \\
\hline 05 & 316 & 164 & 152 & 87 \\
\hline 06 & 367 & 193 & 176 & 104 \\
\hline 07 & 216 & 108 & 106 & 55 \\
\hline 08 & 249 & 121 & 128 & 67 \\
\hline
\end{tabular}

Sumber : Data Potensi Desa Gudang Tengah, 2019

Aktifitas Pasar Desa Gudang Tengah dimulai dari jam 00.00 s.d. 08.00 WITA. Dan aktifitas pasar tidak berhenti kecuali hari libur Agama Islam. Kebanyakan barang yang didagangkan adalah jenis sayur-mayur, buah-buahan dan ikan yang hidup. Terbukti dari sampah yang banyak adalah jenis sayur-mayur dan buah-buahan serta jenis sampah plastik.

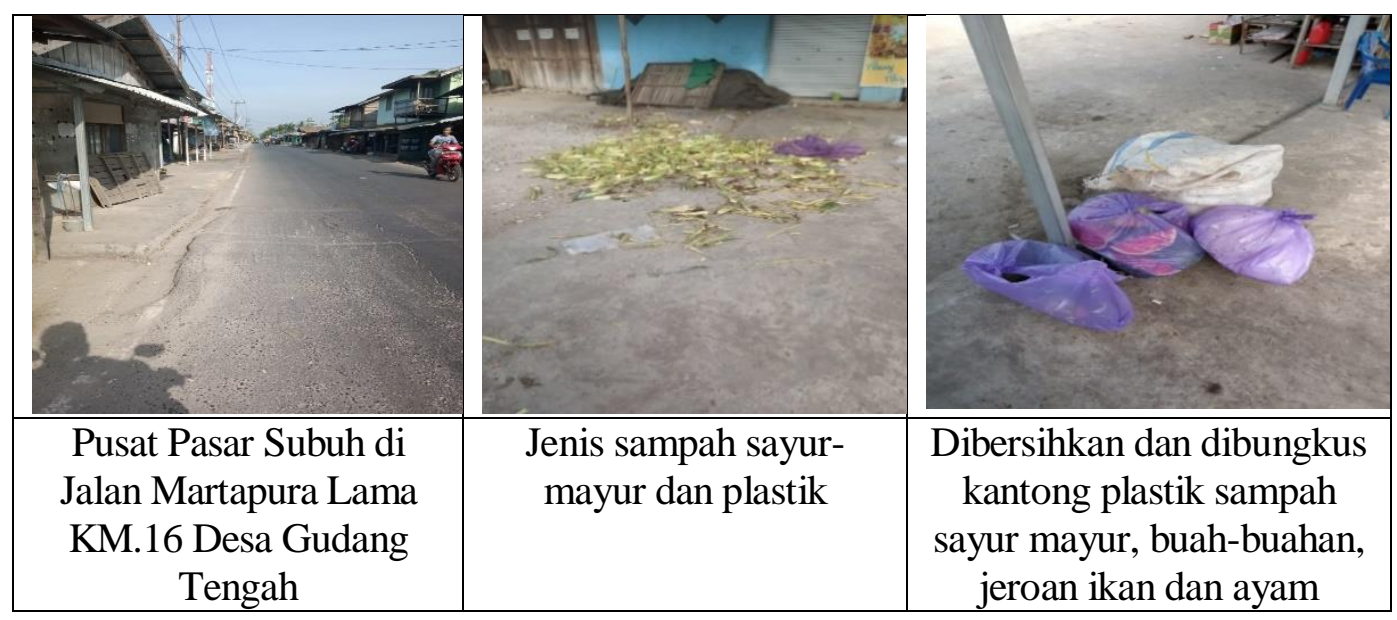

Gambar 3. Photo Kondisi Pasar Desa Gudang Tengah (Sumber : Survei Pasar Gudang Tengah, 25 Agustus 2019)

\section{Identifikasi Masalah}

Berdasarkan uraian pada latar belakang dapat diidentifikasi sejumlah masalah dalam pengelolaan sampah Pasar Desa Gudang Tengah sebagai berikut:

a. Banyaknya sampah Pasar Desa Gudang Tengah yang belum dikelola dengan baik.

b. Masyarakat belum memahami tentang pemilahan sampah.

c. Masyarakat belum memahami tentang teknik pengolahan sampah yang benar.

d. Masyarakat belum memahami tentang nilai guna sampah setelah dilakukan pengolahan.

\section{Rumusan Masalah}

Berdasarkan pertimbangan urgensi permasalahan yang teridentifikasi di atas, maka 
dipilih dua masalah yang hendak dicari-solusinya melalui kegiatan PKM ini. Dari masalah-masalah tersebut dapat dirumuskan masalah sebagai berikut:

a. Kendala-kendala apa saja yang menghambat para pengelola sampah pasar dalam pengelolaan dan pengolahan sampah Desa Gudang Tengah?

b. Bagaimanakah cara pengelolaan dan pengolahan sampah pasar Desa Gudang Tengah yang baik?

\section{Tujuan Penelitian}

Tujuan yang ingin dicapai dengan penelitian ini adalah :

a. Mengetahui kendala-kendala dalam pengelolaan dan pengolahan sampah pasar Desa Gudang Tengah.

b. Memberitahukan cara pengelolaan dan pengolahan sampah pasar Desa Gudang Tengah yang baik melalui konsep $3 \mathrm{R}$ dan Teknologi Lingkungan.

\section{Pembatasan masalah}

Pengelolaan sampah pasar Desa Gudang Tengah masih manual yaitu pekerja sampah mengambil sampah pasar dengan alat angkut sebuah tosa diantarkan ke TPS terdekat. Belum memiliki pengelelolaan sampah yang baik dan belum melihat peluang ekonomi dari sisi pengelolaan sampah. Peraturan Desa mengenai sampah pasar belum begitu jelas dan detail memanyungi pengelolaan sampah pasar. Perlu adanya terobosan atau strategi dalam mengelola sampah pasar Desa Gudang Tengah. Perlu paradigma baru atau konsep dan prosedur pengelolaan sampah pasar Desa Gudang Tengah yang berwawasan lingkungan melalui konsep 3R dan Teknologi lingkungan. Penelitian dibatasi pada penerapan tahapan-tahapan konsep $3 \mathrm{R}$ dan Teknologi Lingkungan yang disosialisasikan kepada masyarakat Desa Gudang Tengah dalam hal ini perangkat desa Gudang Tengah yang mengelola sampah pasar Desa Gudang Tengah.

\section{TINJAUAN PUSTAKA}

\section{Definsi Sampah}

Sampah merupakan suatu bahan yang terbuang atau dibuang dari sumber hasil aktivitas manusia maupun proses alam yang belum memiliki nilai ekonomis (Damanhuri, E., dkk., 2004). Menurut Undang-Undang Republik Indonesia Nomor 18 Tahun 2008 tentang pengelolaan sampah, sampah didefinisikan sebagai sisa kegiatan sehari-hari manusia dan/atau proses alam yang berbentuk padat.

Secara umum sampah dapat diklasifikasikan menjadi 2, yaitu:

1. Sampah organik adalah sampah yang dapat terurai atau membusuk secara alamiah, misalnya sisa sayur-sayuran, buah-buahan, dan daun-daunan. Sampah ini merupakan bagian yang terbesar dari sampah rumah tangga $(+70 \%)$.

2. Sampah anorganik adalah sampah yang tidak dapat terurai atau membusuk secara alamiah dan memerlukan waktu yang sangat lama sekali untuk terurai, misalnya kertas, plastik, kayu-kayuan, kaca, kain, logam, dan lain-lain.

Disamping klasifikasi sampah organik dan anorganik, menurut UU RI No. 18 Tahun 2008, ada juga klasifikasi sampah spesifik. Sampah spesifik adalah sampah yang karena sifat, konsentrasi, dan/atau volumenya memerlukan pengelolaan 
khusus. Adapun sampah yang dikelola berdasarkan UU RI No. 18 Tahun 2008 terdiri atas:

1. Sampah rumah tangga, yaitu sampah yang berasal dari kegiatan sehari-hari dalam rumah tangga, tidak termasuk tinja dan sampah spesifik.

2. Sampah sejenis sampah rumah tangga, yaitu sampah yang berasal dari kawasan komersial, kawasan industri, kawasan khusus, fasilitas sosial, fasilitas umum, dan/atau fasilitas lainnya.

3. Sampah spesifik, yaitu meliputi:
a. sampah yang mengandung bahan berbahaya dan beracun
b. sampah yang mengandung limbah bahan berbahaya dan beracun
c. sampah yang timbul akibat bencana
d. puing bongkaran bangunan
e. sampah yang secara teknologi belum dapat diolah
f. sampah yang timbul secara tidak periodik.

Beberapa teknik yang dapat digunakan untuk pengelolaan sampah perkotaan, antara lain:

1. Sampah diolah menjadi kompos

Sampah biologis, basah atau organik dapat dijadikan kompos dengan cara menimbun sampah tersebut di tanah untuk jangka waktu tertentu hingga membusuk.

2. Sampah digunakan sebagai makanan ternak

Sampah yang berupa buah-buahan dan sayur-sayuran yang belum sepenuhnya rusak dapat dijadikan makanan ternak atau binatang lain yang dikembangbiakkan. Umumnya sampah dari sayur dan buah banyak dijumpai di pasar-pasar tradisional dan berserakan di mana-mana.

3. Metode landfill

Metode ini adalah yang paling mudah karena hanya membuang dan menumpuk sampah di tanah yang rendah pada area yang terbuka. Metode ini sangat mengganggu estetika lingkungan.

4. Metode sanitary landfill

Metode ini mirip dengan metode landfill, namun sampah yang ada ditutup dan diuruk dengan tanah. Metode ini biasanya menggunakan alat-alat berat yang berharga mahal seperti backhoe/eskavator dan buldozer.

5. Metode pulverisation

Pulverisation adalah metode pembuangan sampah langsung ke laut lepas setelah dihancurkan menjadi potongan-potongan kecil.

6. Metode incineration / incinerator

Metode incineration adalah pembakaran sampah baik dengan cara sederhana maupun modern secara masal. Teknologi memungkinkan hasil energi pembakaran diubah menjadi energi listrik (Damanhuri, E., dkk., 2004).

Dari beberapa teknik pengelolaan sampah perkotaan di atas, teknologi yang umum digunakan dalam proses lanjutan setelah sampah ditimbun pada tempat pembuangan akhir (TPA) salah satunya adalah komposting. Komposting adalah teknik menghasilkan kompos yang digunakan sebagai pupuk maupun penguat struktur tanah (Doddy Ari S, Diana S, 2005). 


\section{Konsep 3 R}

Konsep 3 R (Reduce-Reuse-Recyle) dan Teknologi Lingkungan yang disosialisasikan kepada masyarakat Desa Gudang Tengah dalam hal ini perangkat desa Gudang Tengah yang mengelola sampah pasar Desa Gudang Tengah pada Gambar 4 dan alur proses pengelolaan sampah pada Gambar 5. Gambar 6

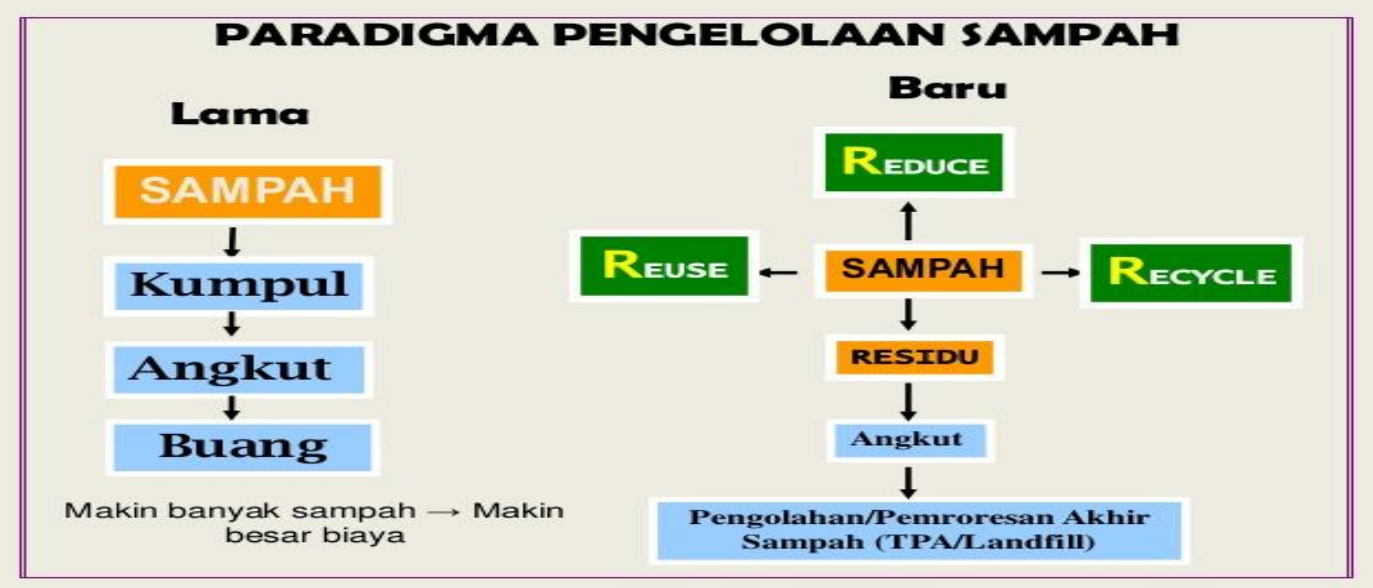

Gambar 4. Pengelolaan Sampah Melalui Konsep 3 R

\section{PROSES PENGELOLAAN SAMPAH}

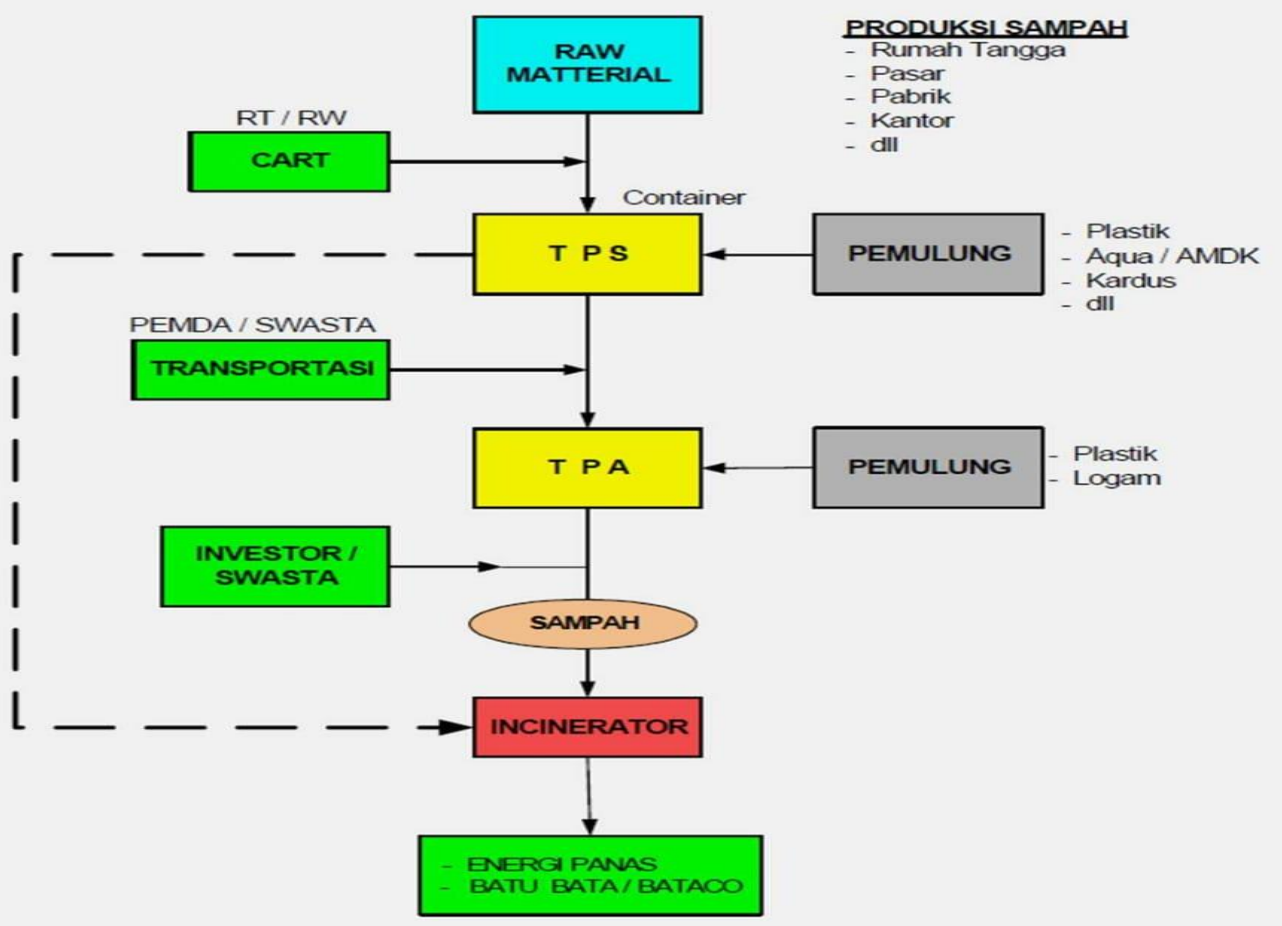

Gambar 5. Diagram Alur Proses Pengelolaan Sampah 


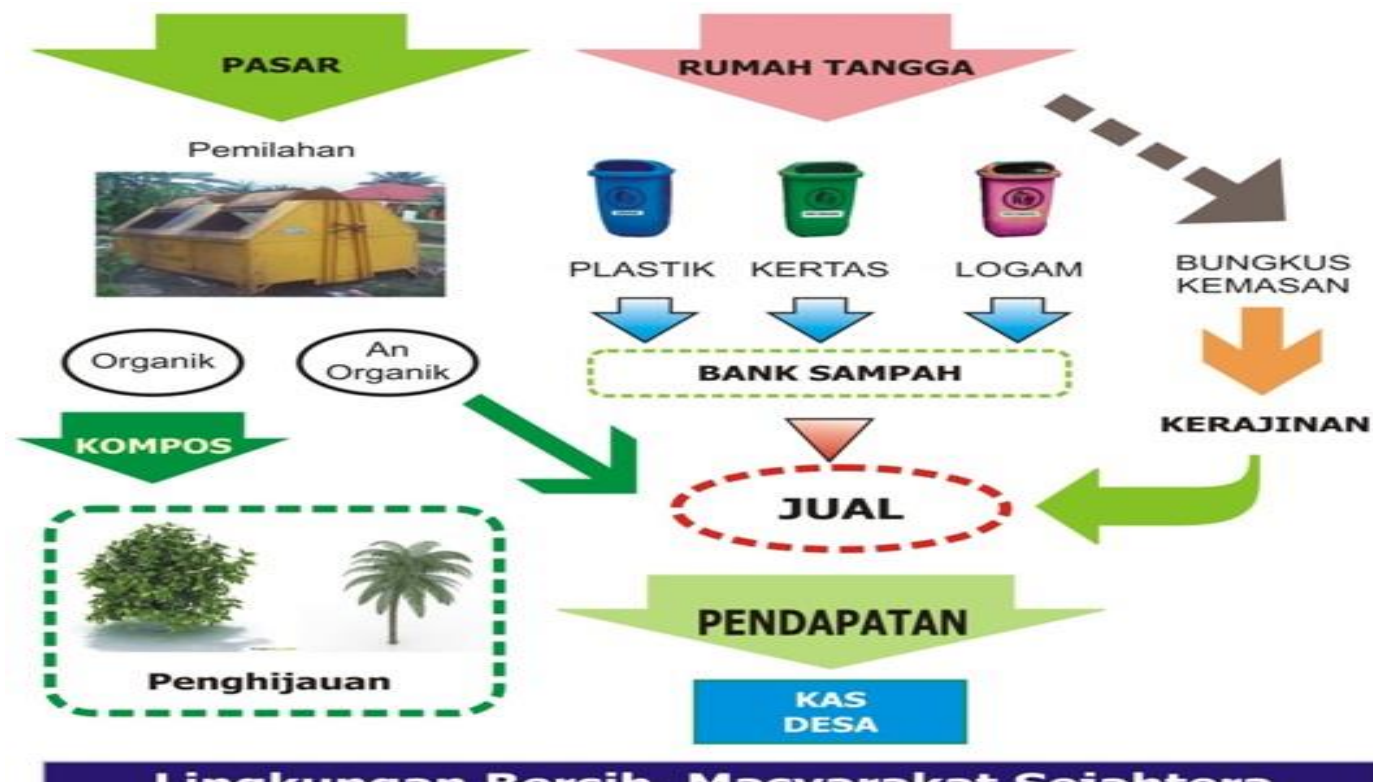

Gambar 6. Konsep Pengelolaan dan Pengolahan Sampah Melalui Konsep 3 R dan Teknologi Lingkungan

\section{Teknologi Lingkungan (Reaktor Kompos)}

Kemajuan teknologi lingkungan dalam pengelohan sampah salah satu yaitu mengelola sampah organik menjadi kompos. Komposting digunakan untuk mempercepat proses degradasi bahan organik dengan bantuan mikroba. Secara alami komposting berlangsung cukup lama, biasanya 3-4 bulan. Untuk mempercepat komposting, diperlukan adanya perlakuan khusus, seperti penggunaan bioreaktor khusus, campuran bahan organik, dan sumber mikroba pengurai. Komposting dapat dilakukan dalam skala besar maupun rumah tangga. Komposting skala rumah tangga menggunakan drum khusus yang didesain untuk mempermudah dan mempercepat proses komposting. Keuntungan komposting skala rumah tangga, yaitu : tidak membutuhkan lahan yang luas, komposting tidak menghasilkan bau yang menganggu dan kontrol mudah dilakukan, sehingga kualitas kompos lebih baik.

Bahan dan alat yang dibutuhkan untuk komposting adalah reaktor kompos, yaitu reaktor yang dapat digunakan bermacam-macam tergantung lokasi, kebutuhan, dan kapasitas sampah. Reaktor tersebut dapat berupa bak terbuka, lubang pada tanah, atau reaktor khusus berbentuk drum. Bahan organik dapat berupa dedaunan, sampah dapur seperti sayuran, nasi, dan sebagainya. Dalam komposting perlu adanya upaya menghindari memasukkan cangkang telur, daging, dan tulang karena akan memperlambat proses pengomposan dan menimbulkan bau busuk. Suplai udara untuk proses degradasi berlangsung secara aerob, sehingga membutuhkan aerasi yang baik. Semakin baik aerasi maka proses degradasi akan semakin cepat. Air untuk pertumbuhan mikroba juga membutuhkan kelembaban 
JURNAL KACAPURI

JURNAL KEILMUAN TEKNIK SIPIL

Volume 2 Nomor 2 Edisi Desember 2019

yang cukup. Oleh karena itu, kompos harus sering disiram agar tetap lembab. Sumber bakteri/jamur pengurai secara sederhana, yaitu mikroba pengurai banyak terdapat di kotoran ternak. Selain itu, mikroba dapat diperoleh dari biakan khusus yang disebut biokatalis atau bioaktifator. Beberapa jenis komposter disajikan dalam Gambar 6 dan Gambar 7 di bawah ini.

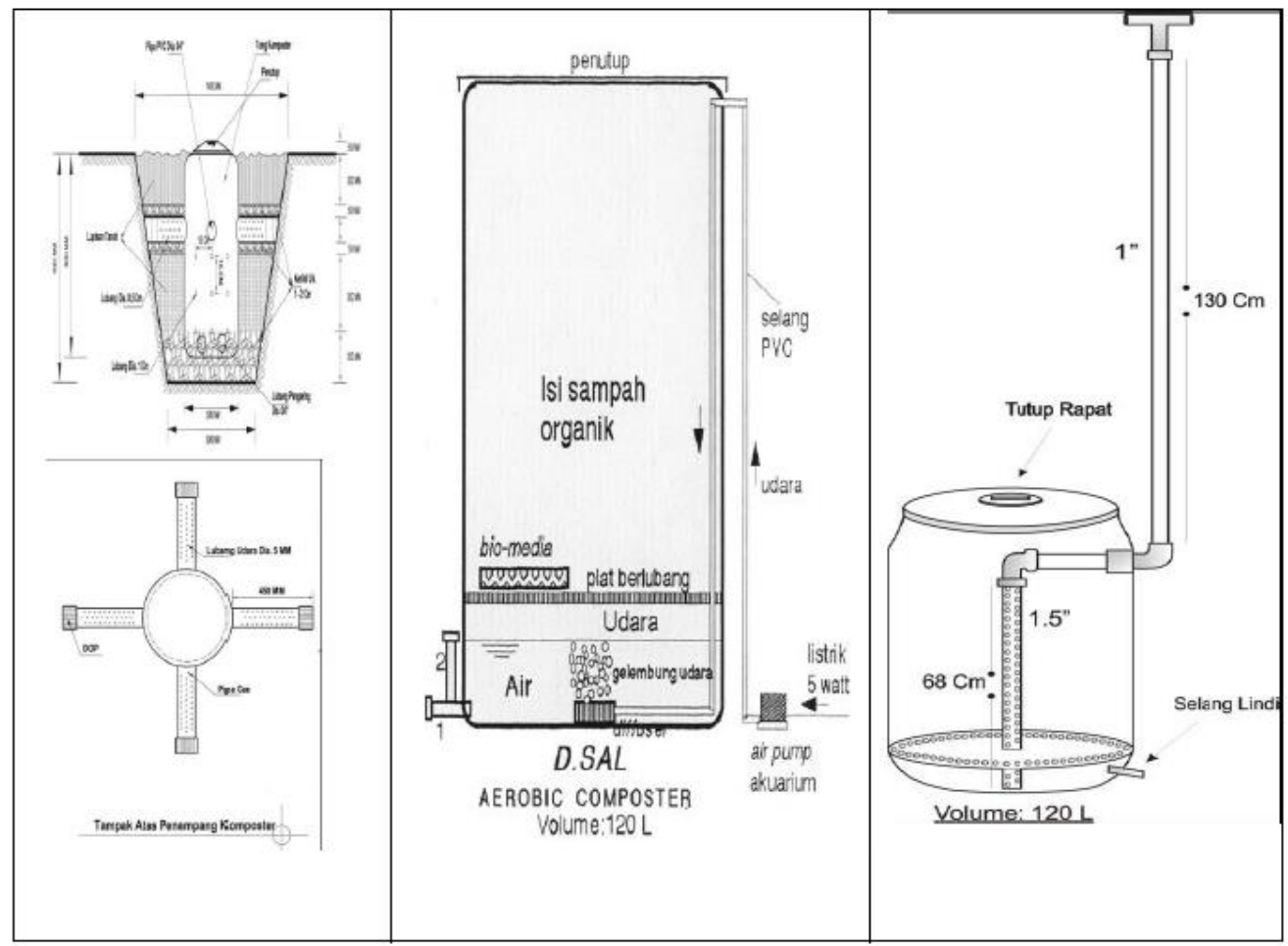

a. Komposter tertanam b. Komposter dengan aerator c. Komposter tanpa aerator

Gambar 6. Jenis-Jenis Komposter

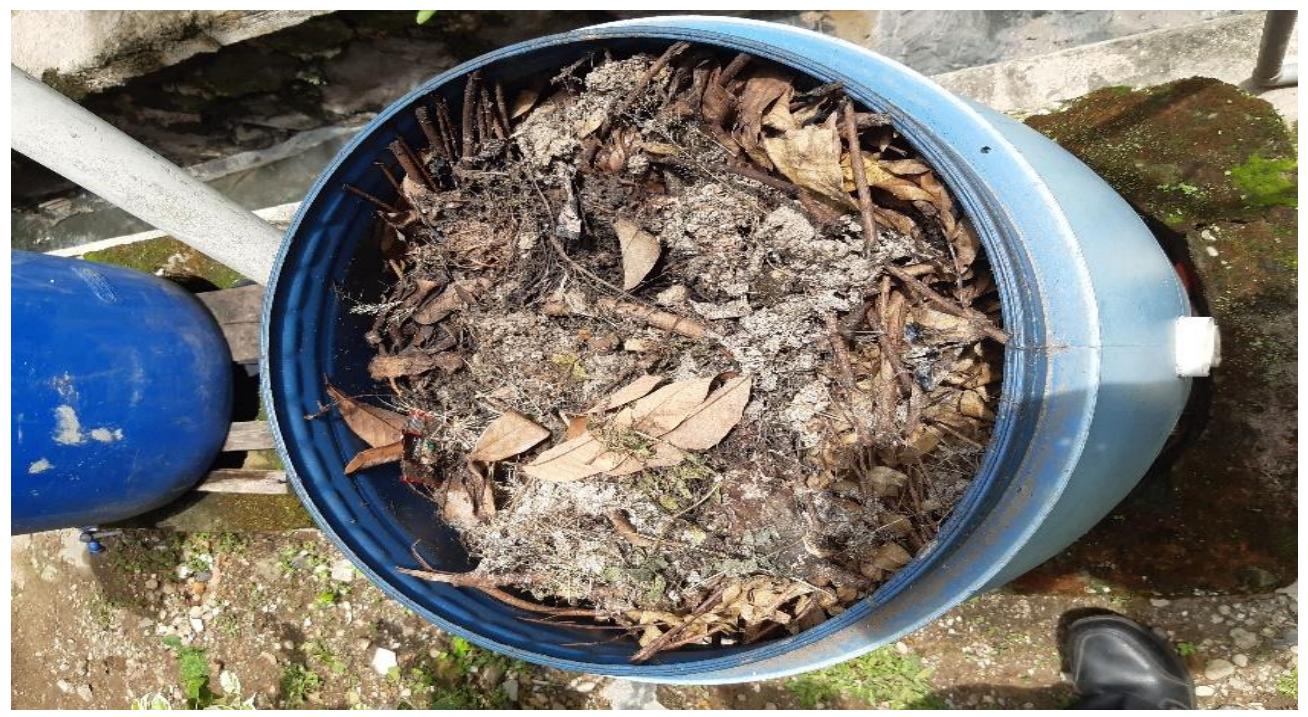

Gambar 7. Reaktor Kompos (Komposter tanpa aerator) 


\section{METODE PENELITIAN}

Metode yang digunakan dalam penelitian ini adalah metode deskriptif-kualitatif. Metode deskriptif-kualittatif analisis dilakukan dengan cara mendeskripsikan, dengan maksud untuk menemukan unsur-unsurnya kemudian dianalisis bahkan juga diperbandingkan. Sehingga dapat disimpulkan bahwa metode deskriptif adalah sebuah cara atau teknik yang dilakukan untuk memaparkan suatu permasalahan sehingga dapat dengan jelas dianalisis dan ditarik kesimpulan. Adapun tahapan metode penlitian sebagai berikut :

1. Sumber Data terdiri dari data primer (didapatkan melalui wawancara dan mengukur lansung ke lapangan) dan data sekunder (didapatkan dari kajiankajian sejenis).

2. Teknik Pengumpulan Data terdiri dari studi kepustakaan (teori konsep $3 \mathrm{R}$ dan teknologi lingkungan) dan studi lapangan (Sosialisasi konsep $3 \mathrm{R}$ dan teknologi lingkungan).

3. Teknik Pembuatan Daftar Pertanyaan. Daftar pertanyaan terdiri dari dua bahasan yaitu: kendala-kendala di lapangan dan solusi dengan sosialisasi penerapan konsep $3 \mathrm{R}$ dan teknologi lingkungan.

4. Teknik Analisis Data. Data diolah dengan menggunakan metode deskriptif kualitatif, kemudian dari analisis yang telah dilakukan diambil suatu kesimpulan.

5. Diagram Alir Penelitian bisa dilihat pada Gambar 6.

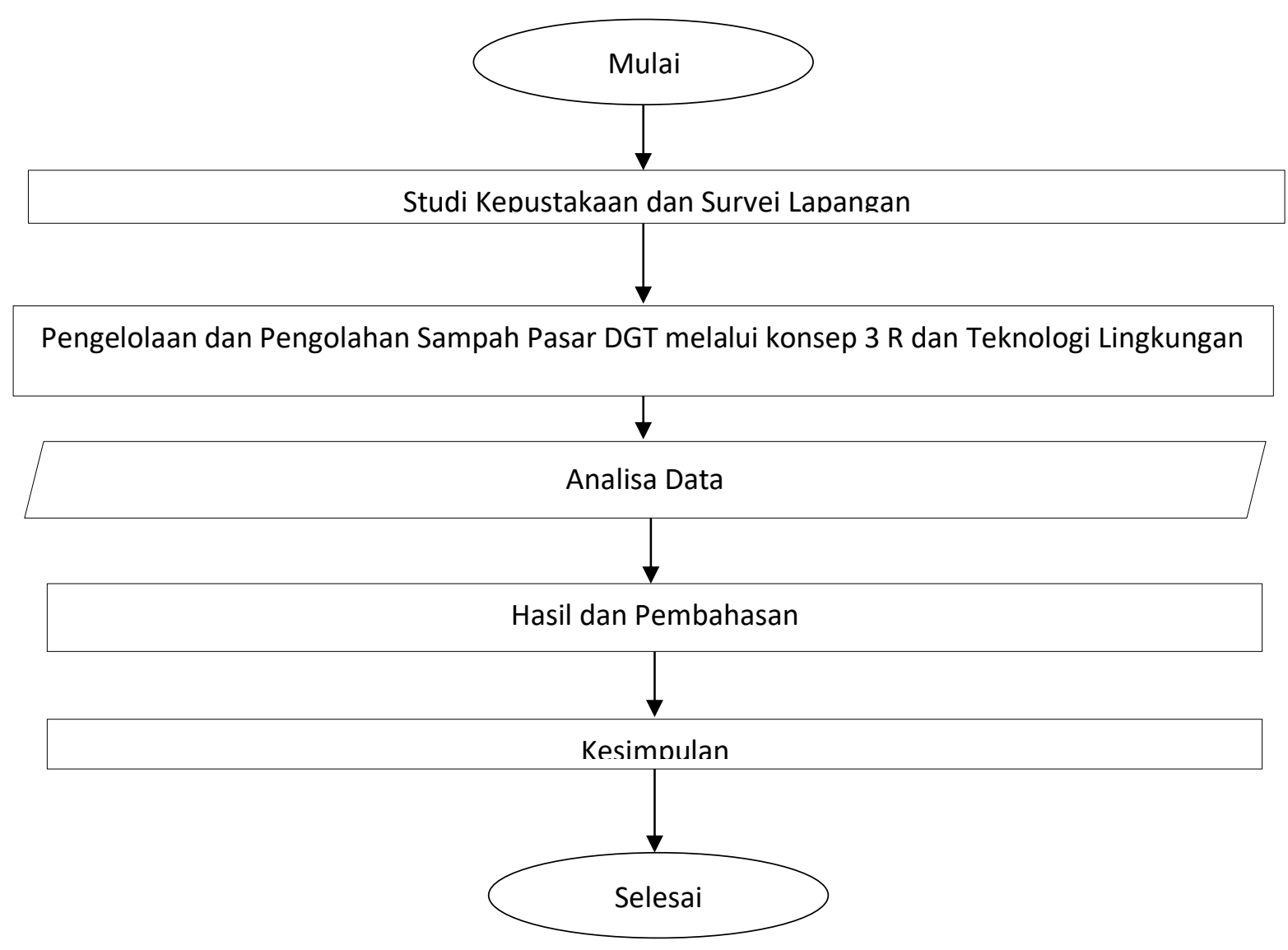

Gambar 6. Diagram Alir Penelitian 


\section{HASIL DAN PEMBAHASAN}

Yang menjadi kendala-kendala dalam Penerapan Konsep $3 \mathrm{R}$ dan Teknologi Lingkungan yaitu :

1. Belum sadarnya masyarakat arti kebersihan lingkungan dan adanya dampak ekonomi langsung apabila mampu mengolah sampah Pasar Desa Gudang Tengah.

2. Belum adanya Bank Sampah baru proses pembentukan struktur organisasi Bank Sampah, diharapkan bisa bersinergi dan diterapkannya Konsep $3 \mathrm{R}$ dan Teknologi Lingkungan.

3. Belum adanya dukungan pemerintah dalam mengelola sampah Desa Gudang Tengah.

Cara atau Teknik tahapan-tahapan pengelolaan dan pengolahan sampah pasar Desa Gudang Tengah melalui kegiatan sosialisasi Pengabdian Kepada Masyarakat (PKM) melalui konsep $3 \mathrm{R}$ (Reduce-Reuse-Recycle) dan Teknologi Lingkungan sebagai berikut :

Tabel 6. Tahapan-tahapan Pengelolaan dan Pengolahan Sampah Pasar Desa Gudang Tengah melalui Konsep 3 R dan Teknologi Lingkungan

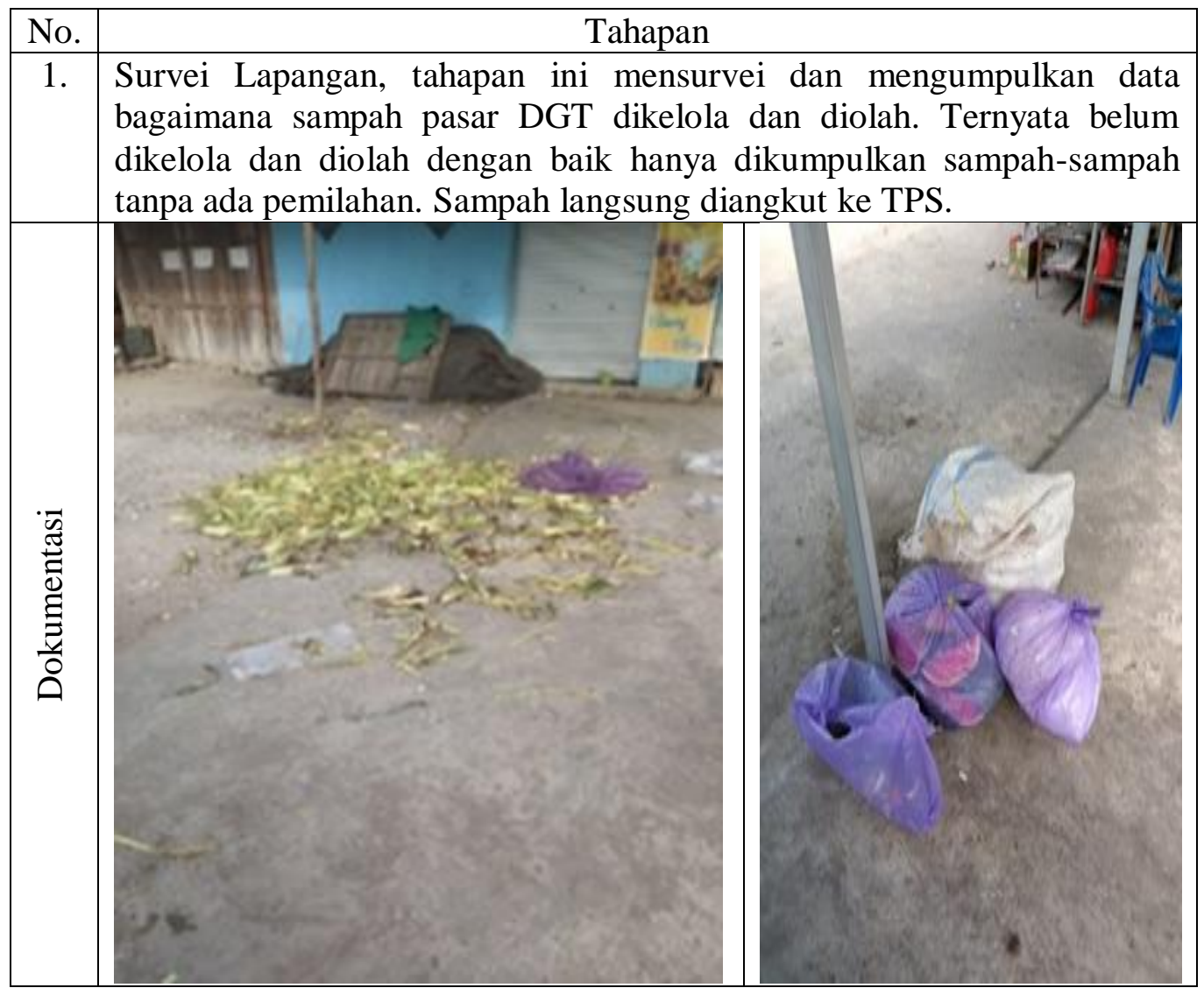


JURNAL KACAPURI

JURNAL KEILMUAN TEKNIK SIPIL

Volume 2 Nomor 2 Edisi Desember 2019

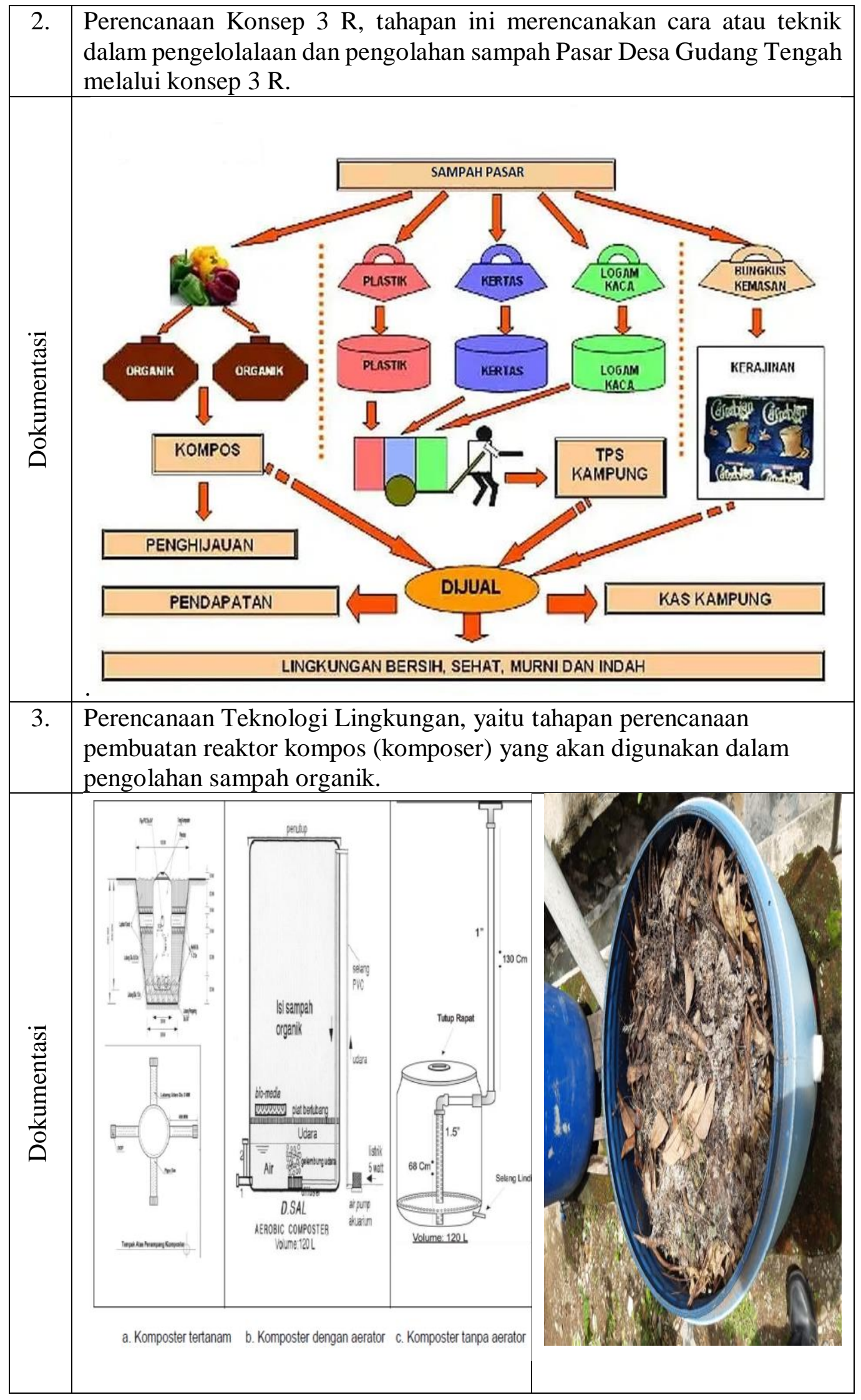


JURNAL KACAPURI

JURNAL KEILMUAN TEKNIK SIPIL

Volume 2 Nomor 2 Edisi Desember 2019

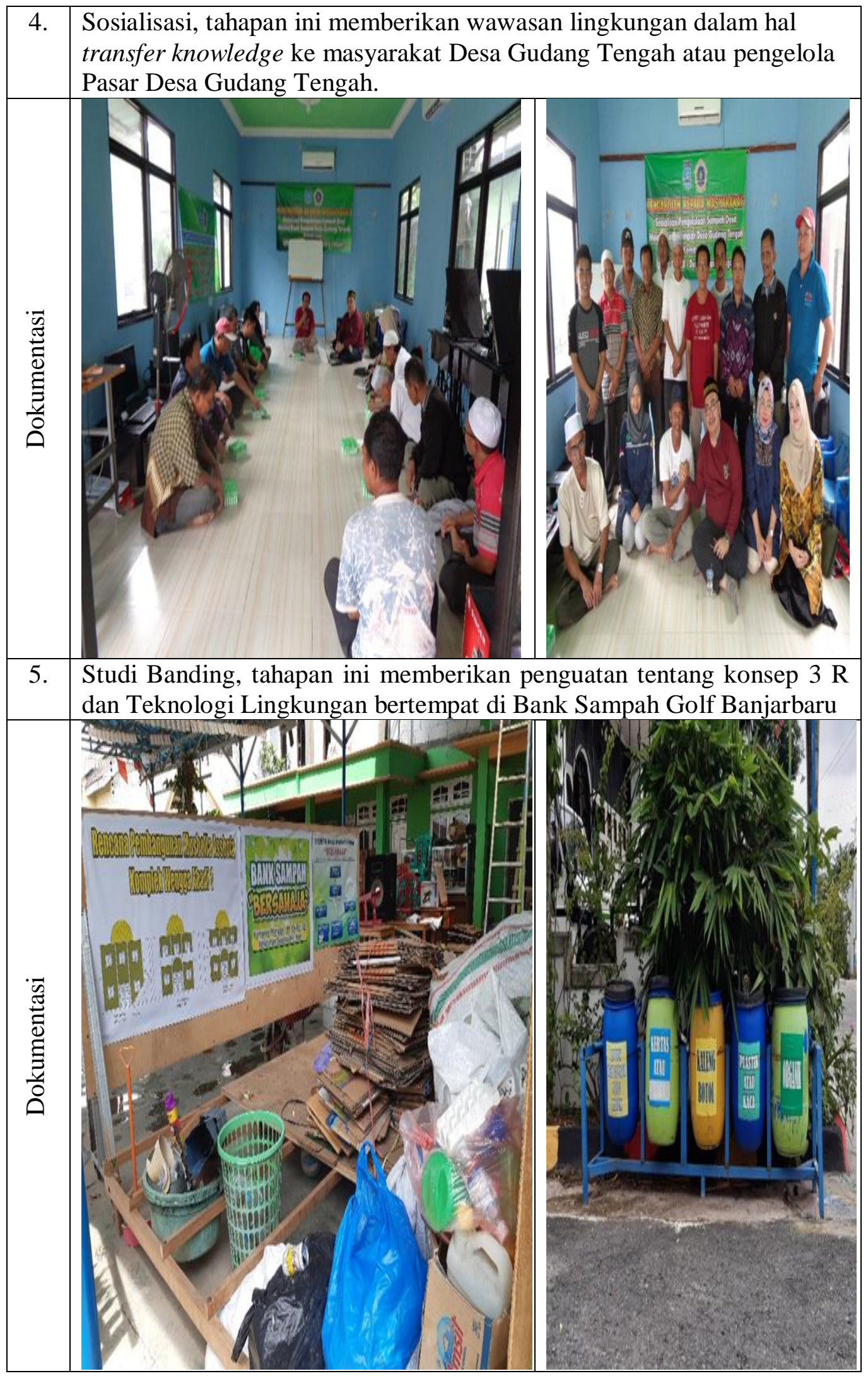

Sumber : Metode deskriptif -kualitatif dan wawancara, 2019. 


\section{PENUTUP}

\section{Kesimpulan}

1. Pelaksanaan Pengabdian Kepada Masyarakat diadakan di Kecamatan Sungai Tabuk Kabupaten Banjar dengan jumlah 24 orang yang hadir (daftar hadir terlampir) terdiri dari pembakal, perangkat desa, ketua RT.01-08, penjual pasar dan mahasiswa.

2. Masyarakat sangat antusias dan menginginkan pengelolaan sampah pasar yang baik berwawasan lingkungan melalui konsep $3 \mathrm{R}$ dan teknologi lingkungan yang diterapkan. Agar lingkungan pasar menjadi bersih dan nyaman serta mendatangkan nilai ekonomis.

3. Masyarakat akan segera membentuk Bank Sampah Desa Gudang Tengah untuk mengurus segala sesuatu berkenaan sampah desa termasuk didalamnya sampah pasar dan sampah rumah tangga.

4. Dengan melalui kegiatan PKM ini didapatkan konsep $3 \mathrm{R}$ (Reduce-ReuseRecycle) dan teknologi lingkungan yang dapat diterapkan dengan baik, menyadarkan masyarakat bahwa sampah bisa mendatangkan nilai ekonomis dengan menukarkan sampah plastik dengan rupiah per $\mathrm{kg}$ melalui Bank Sampah yang akan segera dibentuk.

5. Perlu kedepannya diberikan pelatihan manajemen organisasi bank sampah untuk meningkatkan produksi (pengumpulan jenis sampah yang bernilai ekonomis) dan penjualan (pengempul sampah yang memberikan daftar harga sampah) yang efektif serta menguntungkan bagi masyarakat.

6. Mahasiswa teknik sipil Uniska MAB semakin memahami penerapan konsep 3 $\mathrm{R}$ dan Teknologi Lingkungan ini bisa menguntungkan dan bisa membuka lapangan kerja. Dapat dua keuntungan yang didapat dari kegiatan PKM bagi mahasiswa yaiu kemajuan teknologi dan jiwa wirausaha (enterpreneurship).

\section{Ucapan Terimakasih}

Penulis mengucapkan terimakasih kepada program PKM UNISKA MAB, kawankawan dosen Universitas Islam Kalimantan Muhammad Arsyad Al Banjari, Pembakal dan Masyarakata Desa Gudang Tengah, Mahasiswa Prodi (S-1) Teknik Sipil Uniska MAB serta semua pihak yang telah banyak membantu kelancaran dan selesainya penelitian ini.

\section{DAFTAR PUSTAKA}

Arikunto, Suharsimi, 1987. Prosedur Penelitian suatu Pendekatan Praktek, Jakarta: Radar Jaya Offset.

Bambang Wintoko, 2015. Panduan Praktis Mendirikan Bank Sampah.Yogyakarta: Pustaka baru Press, 2015

Foy, Nancy. 1994. Empowering People at Work, London: Grower Publishing Company.

Hadiwiyoto, S. 1983. Penanganan dan Pemanfaatan Sampah. Jakarta: Yayasan Idayu.

Kartikawan, Yudhi. 2007. "Pengelolaan Persampahan.” Jurnal Lingkungan Hidup, Yogyakarta.

Laporan Potensi Desa Gudang Tengah, 2019. 
Kodoatie, Robert J. 2003. Manajemen dan Rekayasa Infrastruktur. Yogyakarta: Pustaka Pelajar.

. 2005. Pengantar Manajemen Infrastruktur. Yogyakarta: Pustaka Pelajar.

Moleong, Lexi J. 2002. Metodologi Penelitian Kualitatif. Bandung: PT. Remaja Rosdakarya.

Sejati, Kuncoro, 2009. Pengolahan Sampah Terpadu Dengan Sistem Node, Sub Point, Center Point, Yogyakarta : Kanisius.

Soekanto, Soerjono. 1983. Beberapa Teori Sosiologi tentang Struktur Masyarakat. Jakarta: Rajawali Pers.

Soetomo. 2006. Strategi-strategi Pembangunan Masyarakat. Yogyakarta: Pustaka Pelajar.

Sumaryadi, I Nyoman. 2005. Perencanaan Pembangunan Daerah Otonom dan Pemberdayaan Masyarakat. Jakarta: Penerbit Citra Utama.

Profil Kabupaten Banjar Dalam Angka 2018, BPS, 2019.

Tuti Kustiah. 2005. Kajian Kebijakan Pengelolaan Sanitasi Berbasis Masyarakat. Pusat Penelitian dan Pengembangan Permukiman, Badan Penelitian dan Pengembangan Departemen Pekerjaan Umum. Bandung.

Yarianto, dkk. 2005. "Perlu Paradigma Baru Pengelolaan Sampah.” Jakarta.

http://ww.sinarharapan.co.id, diunduh pada tanggal 5 Juni 2011.

https://itk.ac.id/pengelolaan-sampah-modern-demi-sumber-energi-berkelanjutan/ http://lipi.go.id/berita/solusi-teknologi-terkini-pengolahan-sampah-/304

http://staffnew.uny.ac.id/upload/132255132/pengabdian/3-pengelolaan-sampahrumah-tangga-2008.pdf

http://digilib.uin-suka.ac.id/26543/1/10250023_BAB-I_IV-atau-V_DAFTARPUSTAKA\% $20 \% 282 \% 29$.pdf 